\title{
PENGARUH PROMOSI JABATAN, DAN KOMPENSASI TERHADAP KEPUASAN KERJA KARYAWAN PADA PT. PERKEBUNAN NUSANTARA III LABUHAN HAJI.
}

\section{Desmawaty Hasibuan}

\author{
Dosen Tetap Sekolah Tinggi Ilmu Ekonomi (STIE) Labuhan Batu
}

\section{ABSTRAK}

PT. Perkebunan Nusantara III Labuhan Haji yang merupakan perusahaan negara yang bergerak dibidang perkebunan. Pengambilkan keputusan masih sulit diterapkan secara objektif karena adanya unsur subjektifitas dalam penilaian seperti faktor social, dan faktor non social, penelitian ini bertujuan untuk mengetahui pengaruh promosi jabatan dan kompensasi pada PT. Perkebunan Nusantara III Labuhan Haji terhadap kepuasan kerja karyawan.

Populasi dalam penelitian ini adalah karyawan yang berjumlah 508 Orang karyawan PT. Perkebunan Nusantara III Labuhan Haji. Dengan jumlah sampel 50 orang. Adapun analisis yang digunakan adalah analisis regresi liniear berganda dengan menggunakan bantuan software SPSS 20.00 for windows. Analisis regresi berganda menggunakan persamaan, sebagai berikut:

$$
Y=a+b_{1} X_{1}+b_{2} X_{2}+e
$$

Adapun hasil penelitian ini menunjukkan promosi jabatan dan kompensasi secara bersama - sama berpengaruh positif dan signifikan terhadap kepuasan kerja karyawan PT. Perkebunan Nusantara III Labuhan Haji, hal ini terlihat dari nilai R Square pada kolom ketiga (angka korelasi atau $r$ yang dikuadratkan) sebesar 0,681 atau sebesar 68,1\%, sisanya yaitu $31,9 \%$ dapat dijelaskan variabel lain yang tidak termasuk dalam model penelitian ini.

Kata Kunci : Promosi Jabatan, Kompensasi, Kepuasan Kerja

\section{PENDAHULUAN}

Karyawan dan perusahaan merupakan dua hal yang tidak bisa dipisahkan. Karyawan memegang peran utama dalam menjalankan roda kehidupan perusahaan. Apabila karyawan memiliki produktivitas dan motivasi kerja yang tinggi, maka laju roda pun akan berjalan kencang, yang akhirnya akan menghasilkan kinerja dan pencapaian yang baik bagi perusahaan. Di sisi lain, bagaimana mungkin roda perusahaan berjalan baik, kalau karyawannya bekerja tidak produktif, artinya karyawan tidak memiliki semangat kerja yang tinggi, tidak ulet dalam bekerja dan memiliki moril yang rendah.

Kepuasan kerja adalah perasaan dan penilaian seorang atas pekerjaannya, khususnya 
menegenai kondisi kerjanya, dalam hubungannya dengan apakah pekerjaannya mampu memenuhi harapan, kebutuhan, dan keinginannya". Kepuasan kerja dengan sikap dari karyawan terhadap pekerjaannya sendiri, situasi kerja, kerjasama antara pimpinan dengan sesama karyawan sejalan dengan itu, kepuasan kerja (job salisfaction) adalah keadaan emosional karyawan di mana terjadi ataupun tidak terjadi titik temu antara nilai balas jasa kerja karyawan dari perusahaan atau organisasi dengan tingkat nilai balas jasa yang memang diinginkan oleh karyawan yang bersangkutan. Balas jasa kerja karyawan ini, baik yang berupa finansial maupun yang nonfinansial.

Promosi jabatan juga diartikan sebagai penghargaan atas keberhasilan karyawan menunjukkan prestasi kerja yang tinggi pada pelaksana tugas-tugas yang dilimpahkan oleh perusahaan kepadanya. Sistem dan perencanaan promosi jabatan pada suatu organisasi akan membuat karyawan menjadi lebih giat bekerja, bersemangat dan berdisiplin, sehingga menciptakan suatu kepuasan kerja bagi masing-masing karyawan dan tujuan perusahaan dapat tercapai secara optimal.

Kompensasi merupakan sesuatu yang diterima karyawan sebagai pengganti kontribusi jasa mereka pada perusahaan. Pemberian kompensasi merupakan salah satu pelaksanaan fungsi MSDM yang berhubungan dengan semua jenis pemberian penghargaan individual sebagai pertukaran dalam melakukan tugas keorganisasian.

Karyawan dipacu untuk meningkatkan kualifikasinya agar mampu menempati posisi yang lebih tinggi di perusahaan. Peningkatan kualifikasi sangat penting untuk dilakukan oleh setiap karyawan agar mereka memiliki keunggulan terhadap karyawan lain yang juga menginginkan suatu promosi jabatan. Karyawan akan berupaya untuk meningkatkan kemampuannya agar dapat menjadi kandidat yang layak untuk di promosikan.

Pemberian kompensasi harus dilakukan secara adil dan merata, karena karyawan cenderung untuk membandingkan besarnya kompensasi berdasarkan input yang telah mereka berikan kepada perusahaan dan juga membandingkannya dengan jumlah kompensasi yang diterima karyawan lain dengan tingkat tugas dan jabatan yang sama serta membandingkannya dengan karyawan lain di perusahaan sejenis. 
Semakin positif persepsi karyawan akan kompensasi maka akan mampu meningkatkan kepuasan kerja karyawan, begitu pula sebaliknya bila karyawan memiliki persepsi negatif terhadap kompensasi maka akan mampu menurunkan kepuasan kerjanya.

Berdasarkan latar belakang yang diuraikan secara teoritis, maka perlu dikaji lebih rinci melalui penelitian empiris guna mendukung hasil penelitian-penelitian mengenai pengaruh promosi jabatan dan kompensasi Terhadap kepuasan kerja karyawan pada PT.Perkebunan Nusantara III Labuhan Haji.

\section{Rumusan Masalah}

Adapun permasalahan dalam penelitian ini adalah :

1 Bagaimana pengaruh promosi jabatan terhadap kepuasan kerja karyawan pada PT. Perkebunan Nusantara III Labuhan Haji.

2 Bagaimana pengaruh kompensasi terhadap kepuasan kerja karyawan pada PT. Perkebunan Nusantara III Labuhan Haji.

3 Bagaimana pengaruh promosi jabatan dan kompensasi terhadap kepuasan kerja karyawan pada PT.Perkebunan Nusantara III Labuhan Haji

\section{A. Tujuan Penelitian}

Adapun tujuan penelitian ini adalah:

1. Untuk mengetahui promosi jabatan Terhadap kepuasan kerja karyawan pada PT. Perkebunan Nusantara III Labuhan Haji .

2. Untuk mengetahui kompensasi Terhadap kepuasan kerja karyawan pada PT. Perkebunan Nusantara III Labuhan Haji.

3. Untuk mengetahui pengaruh promosi jabatan dan kompensasi terhadap kepuasan kerja karyawan pada PT.Perkebunan Nusantara III Labuhan Haji.

\section{LANDASAN TEORI}




\section{Jurnal Ecobisma Vol 5 No. 2 Juni 2018}

\section{Promosi Jabatan}

Menurut Hasibuan (2012) bahwa "Promosi jabatan berarti perpindahan yang memperbesar wewenang dan tanggung jawab ke jabatan yang lebih tinggi di dalam suatu organisasi yang diikuti dengan kewajiban, hak, status, dan penghasilan yang lebih besar."

Menurut Siagian (2012) : "Promosi adalah perpindahan pegawai dari satu pekerjaan ke pekerjaan lain yang tanggung jawabnya lebih besar, tingkatan hirarki jabatannya lebih tinggi dan penghasilannya pun lebih besar pula."

\section{Kompensasi}

Menurut Hasibuan (2012) mendefinisikan kompensasi adalah: semua pendapatan yang berbentuk uang, barang langsung atau tidak langsung yang diterima karyawan sebagai imbalan atau jasa yang diberikan kepada perusahaan. Kompensasi berbentuk uang, artinya kompensasi dibayar dengan sejumlah uang kartal kepada karyawan.

\section{Kepuasan Kerja}

Menurut Handoko (2012), menyatakan bahwa : " Kepuasan kerja adalah keadaan emosional yang menyenangkan atau tidak menyenangkan dimana para karyawan memanadang pekerjaan mereka."

Rivai (2005) mendefinisikan kepuasan kerja sebagai : Kepuasan kerja pada dasarnya merupakan sesuatu yang bersifat individual. Makin tinggi penilaian terhadap kegiatan dirasakan sesuai dengan keinginan individu, maka makin tinggi pula kepuasannya terhadap kegiatan tersebut.

\section{METODE PENELITIAN}

\section{Populasi dan Sampel}

Menurut Sugiyono (2014) populasi adalah wilayah generalisasi yang terdiri atas: obyek/subyek yang mempunyai kualitas dan karakteristik tertentu yang ditetapkan oleh peneliti untuk dipelajari dan kemudian ditarik kesimpulannya. Menurut Arikunto, (2010) Populasi adalah keseluruhan subyek penelitian. Maka, yang menjadi populasi adalah seluruh karyawan 508 Orang karyawan PT. Perkebunan Nusantara III Labuhan Haji orang ka ryawan. Menurut Arikunto, (2010) Sampel merupakan bagian yang diambil dari populasi. Sedangkan menurut Sugiyono (2014) sampel merupakan bagian dari populasi yang dipilih dengan menggunakan 
aturan-aturan tertentu, yang digunakan untuk mengumpulkan informasi/data yang menggambarkan sifat atau ciri yang dimiliki populasi. Arikunto, (2010) yang menyebutkan bahwa jika populasi lebih dari 100 orang maka sebaiknya diambil antara 10 - 40\%. Maka peneliti menetapkan sampel berjumlah $10 \%$ dari total populasi yaitu $10 \%$ x 508 orang sampel $=50,8$ orang dibulatkan kebawah menjadi 50 orang sampel.

\section{Metode Analisis Data}

Teknik analisis data yang digunakan adalah :

\section{Deskriptif Statistik}

Analisis deskriptif, merupakan suatu cara menganalisis dimana data yang sudah dikumpulkan, dikelompokkan, dianalisis dan diinterpretasikan sehingga diperoleh gambaran yang jelas tentang objek yang diteliti.

\section{Analisis Regresi Linier Berganda}

Analisis regresi liniear berganda digunakan untuk mengetahui pengaruh variabel bebas (X) yang lebih dari 2 (dua) variabel terhadap variabel terikat (Y). Pengolahan data dilakukan dengan menggunakan bantuan software SPSS 20.00 for windows. Analisis regresi berganda menggunakan persamaan, sebagai berikut:

$$
\mathbf{Y}=\mathbf{a}+\mathbf{b}_{1} \mathbf{X}_{1}+\mathbf{b}_{2} \mathbf{X}_{2}+\mathbf{e}
$$

$\begin{array}{ll}\text { Keterangan : } & \\ \mathrm{Y} & =\text { Kepuasan kerja } \\ \mathrm{a} & =\text { Konstanta } \\ \mathrm{b}_{1}-\mathrm{b}_{2} & =\text { Promosi Jabatan } \\ \mathrm{X}_{1} & =\text { Kompensasi } \\ \mathrm{X}_{2} & =\text { Standart error } \\ \mathrm{e} & \end{array}$




\section{Jurnal Ecobisma Vol 5 No. 2 Juni 2018}

\section{Uji Hipotesis}

Setelah persamaan regresi didapat, maka tahap berikutnya adalah melakukan pengujian terhadap hipotesis penelitian untuk mengetahui apakah variabel Promosi jabatan ( $\left.\mathrm{X}_{1}\right)$, Kompensasi $\left(\mathrm{X}_{2}\right)$, dapat digunakan untuk memprediksi variabel kepuasan kerja $(\mathrm{Y})$.

Pengujian hipotesis tersebut dilakukan dengan uji statistik yaitu :

a. Uji Simultan (Uji F)

Uji statistik F pada dasarnya menunjukkan apakah semua variabel independen promosi jabatan $\left(\mathrm{X}_{1}\right)$, kompensasi $\left(\mathrm{X}_{2}\right)$, dapat digunakan untuk memprediksi variabel kepuasan kerja (Y).

Kriteria pengujian :

Jika tingkat signifikansi F $>0,05$ atau $\mathrm{F}$ hitung $<\mathrm{F}$ tabel, maka Ho diterima.

Jika tingkat signifikansi $\mathrm{F}<0,05$ atau $\mathrm{F}$ hitung $>\mathrm{F}$ tabel, maka Ho ditolak.

b. Uji Parsial (Uji t)

Uji statistik pada dasarnya menunjukkan seberapa jauh pengaruh variabel promosi jabatan $\left(\mathrm{X}_{1}\right)$, kompensasi $\left(\mathrm{X}_{2}\right)$, dapat digunakan untuk memprediksi variabel kepuasan kerja (Y).

Kriteria pengujiannya sebagai berikut:

Jika probabilitas (signifikansi) lebih besar dari 0,05 $(\alpha)$, maka variabel independen secara individual tidak berpengaruh terhadap variabel dependen.

Jika probabilitas (signifikansi) lebih kecil dari 0,05 ( $\alpha$ ), maka variabel independen secara individual berpengaruh terhadap variabel dependen. Kriteria pengujian :

Ho diterima dan Ha ditolak jika $t$ hitung kurang dari $t$ tabel. Artinya variabel independen tersebut tidak berpengaruh secara signifikan terhadap variabel dependen. 
Ho ditolak dan Ha diterima jika t hitung lebih besar dari t tabel. Artinya variabel independen tersebut berpengaruh secara signifikasi terhadap variabel dependen.

\section{HASIL PENELITIAN}

\section{Hasil Analisis Regresi Linier Berganda}

Analisis regresi linear berganda bertujuan untuk mengetahui pengaruh dari variabelvariabel independen terhadap variabel dependen, dapat dilihat pada tabel 1berikut ini:

\section{Tabel 1}

\section{Hasil Analisis Regresi Linier Berganda}

\section{Coefficients $^{\mathrm{a}}$}

\begin{tabular}{|c|c|c|c|c|c|c|}
\hline \multirow{2}{*}{\multicolumn{2}{|c|}{ Model }} & \multicolumn{2}{|c|}{$\begin{array}{c}\text { Unstandardized } \\
\text { Coefficients }\end{array}$} & \multirow{2}{*}{$\begin{array}{l}\text { Standardized } \\
\text { Coefficients } \\
\text { Beta }\end{array}$} & \multirow[t]{2}{*}{$\mathrm{t}$} & \multirow[t]{2}{*}{ Sig. } \\
\hline & & B & Std. Error & & & \\
\hline \multirow{3}{*}{1} & (Constant) & 2.505 & 1.873 & & 1.337 & .188 \\
\hline & PromosiJabatan & .764 & .081 & .792 & 9.465 & .000 \\
\hline & Kompensasi & .112 & .071 & .132 & 2.583 & .120 \\
\hline
\end{tabular}

a. Dependent Variable: Kepuasan kerja

Model persamaan regresi berganda dapat dilihat dibawah ini:

$$
Y=2.505+0,764 X_{1}+0,112 X_{2}
$$

\section{Keterangan :}

a) Koefisien regresi konstanta sebesar 2.505 mempunyai arti jika ada atau terjadi promosi jabatan dan kompensasi, maka kepuasan kerja karyawan sebesar 2.505. 
b) Koefisien regresi promosi jabatan sebesar 0,764 mempunyai arti bahwa setiap terjadi penambahan promosi jabatan sebesar 0,764 maka kepuasan kerja karyawan sebesar 1 kali.

c) Koefisien regresi kompensasi sebesar 0,112 mempunyai arti bahwa setiap terjadi penambahan kompensasi sebesar 0,112 maka kepuasan kerja karyawan sebesar 1 kali.

\section{Pengujian Hipotesis}

\section{a) Hasil Uji Serempak (Uji F)}

Uji F ini dilakukan untuk menguji secara serempak apakah promosi jabatan dan kompensasi berpengaruh terhadap kepuasan kerja, dapat dilihat pada Tabel 1.1 berikut:Tabel 1.1

\section{Hasil Uji Serempak (Uji F)}

$\operatorname{ANOVA}^{\mathbf{a}}$

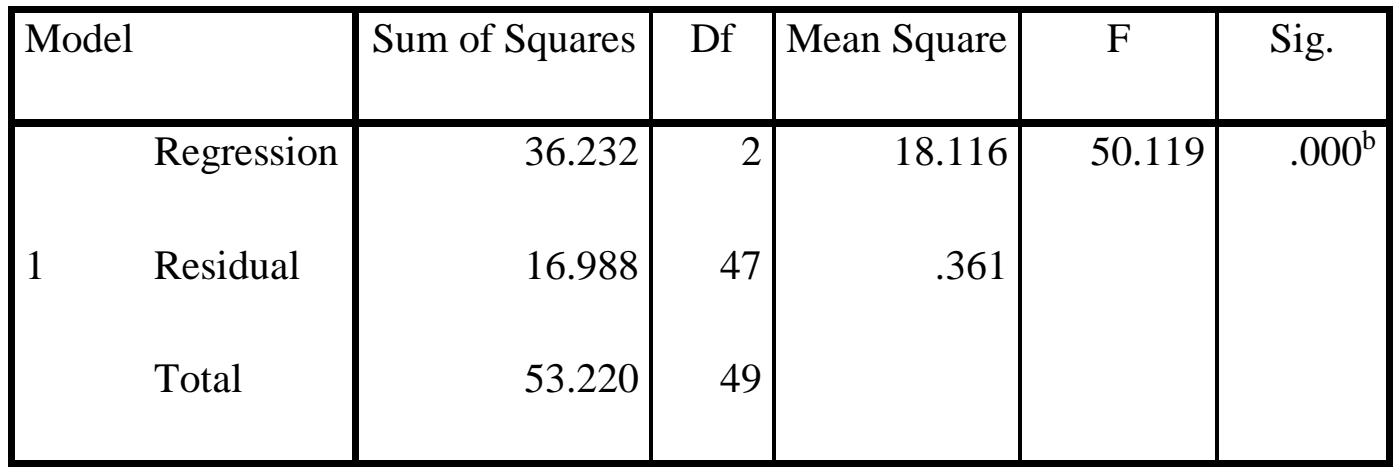

a. Dependent Variable: Kepuasan kerja

b. Predictors: (Constant), Kompensasi, Promosi Jabatan

Tabel 1.1 menunjukkan hasil uji-F untuk koefisien korelasi persamaan regresi diperoleh nilai $\mathrm{F}$ hitung sebesar 50.119 dengan tingkat signifikan sebesar 0.000. Nilai $\mathrm{F}$ tabel dicari pada tabel $\mathrm{F}$ dengan $\mathrm{df}_{1}=2$ dan $\mathrm{df} 2=47$ sehingga diperoleh nilai $\mathrm{F}$ tabel sebesar 3,20 dengan hasil tersebut dimana $\mathrm{F}$ hitung $>\mathrm{F}$ tabel dan nilai signifikan yang lebih kecil dari pada alpha 5\% maka kesimpulan yang dapat diambil adalah signifikan secara statisik. Hipotesis Ha diterima karena $\mathrm{F}$ hitung $>\mathrm{F}$ tabel $(50.119>3,20)$ dan signifikan $\mathrm{F}<$ alpha $5 \%(0,000<0,05)$ yang berarti bahwa 
secara bersama-sama terdapat pengaruh signifikan antara promosi jabatan dan kompensasi terhadap kinerja karyawan PT. Perkebunan Nusantara III Labuhan Haji Kabupaten Labuhanbatu Utara.

\section{b. Hasil Uji Parsial (Uji t)}

Uji parsial (uji t) dilakukan untuk menguji secara parsial (individu) apakah gaji dan insentif berpengaruh terhadap kinerja karyawan PT. Perkebunan Nusantara III Labuhan Haji Kabupaten Labuhanbatu Utara, dapat dilihat pada Tabel 1.2 berikut :

\section{Tabel 1.2}

\section{Hasil Uji Parsial (Uji t)}

\section{Coefficients $^{\mathrm{a}}$}

\begin{tabular}{|c|c|c|c|c|c|c|}
\hline \multirow{2}{*}{\multicolumn{2}{|c|}{ Model }} & \multicolumn{2}{|c|}{$\begin{array}{l}\text { Unstandardized } \\
\text { Coefficients }\end{array}$} & \multirow{2}{*}{$\begin{array}{l}\text { Standardized } \\
\text { Coefficients } \\
\text { Beta }\end{array}$} & \multirow[t]{2}{*}{$\mathrm{T}$} & \multirow[t]{2}{*}{ Sig. } \\
\hline & & B & Std. Error & & & \\
\hline \multirow{3}{*}{1} & (Constant) & 2.505 & 1.873 & & 1.337 & .188 \\
\hline & PromosiJabatan & .764 & .081 & .792 & 9.465 & .000 \\
\hline & Kompensasi & .112 & .071 & .132 & 2.583 & .120 \\
\hline
\end{tabular}

a. Dependent Variable: Kepuasan kerja

Tabel 1.2 menunjukkan nilai t-hitung untuk variabel promosi jabatan $(9,465)$ dengan nilai sig sebesar 0,000, kompensasi sebesar $(2,583)$ nilai sig sebesar 0,120, sedangkan untuk nilai t tabel dicari pada tabel $\mathrm{t}$ dengan level of test $\alpha=5 \%$ dan $\mathrm{df}_{1}=50$ sehingga diperoleh nilai $\mathrm{t}$ tabel sebesar 1.675

Maka $t_{\text {hitung }}>\mathrm{t}_{\text {tabel }}(9,465>1,675)$ secara parsial variabel promosi jabatan berpengaruh positif dan signifikan terhadap kepuasan kerja karyawan PT. Perkebunan Nusantara III Labuhan Haji dan $\mathrm{t}$ hitung $<\mathrm{t}$ tabel $(2,583>1,675)$ secara parsial variabel kompensasi berpengaruh positif dan 


\section{Jurnal Ecobisma Vol 5 No. 2 Juni 2018}

signifikan terhadap kepuasan kerja karyawan PT. Perkebunan Nusantara III Labuhan Haji Kabupaten Labuhanbatu Utara

\section{PEMBAHASAN}

1) Secara Parsial Promosi Jabatan dan Kompensasi Berpengaruh Pada Kepuasan kerja karyawan PT. Perkebunan Nusantara III Labuhan Haji Kabupaten Labuhanbatu Utara.

Hasil uji-F untuk koefisien korelasi persamaan regresi diperoleh nilai $\mathrm{F}$ hitung sebesar 50.119 dengan tingkat signifikan sebesar 0.000. Nilai $\mathrm{F}$ tabel dicari pada tabel $\mathrm{F}$ dengan $\mathrm{df}_{1}=2$ dan df $2=47$ sehingga diperoleh nilai $\mathrm{F}$ tabel sebesar 3,20 dengan hasil tersebut dimana $\mathrm{F}$ hitung $>$ F tabel dan nilai signifikan yang lebih kecil dari pada alpha 5\% maka kesimpulan yang dapat diambil adalah signifikan secara statisik.

Hipotesis Ha diterima karena F hitung > F tabel $(50.119>3,20)$ dan signifikan $\mathrm{F}<$ alpha $5 \%(0,000<0,05)$ yang berarti bahwa secara parsial terdapat pengaruh signifikan antara promosi jabatan dan kompensasi terhadap kepuasan kerja karyawan PT. Perkebunan Nusantara III Labuhan Haji Kabupaten.

Hasil uji t dicari dengan melihat $\mathrm{t}_{\text {tabel }}=1,675$, maka $\mathrm{t}_{\text {hitung }}>\mathrm{t}_{\text {tabel }}(9,465>1,675)$ secara parsial variabel promosi jabatan berpengaruh positif dan signifikan terhadap kepuasan kerja karyawan dan $\mathrm{t}$ hitung $<\mathrm{t}_{\text {tabel }}(1,583<1,675)$ secara parsial variabel kompensasi tidak berpengaruh terhadap kepuasan kerja karyawan PT. Perkebunan Nusantara III Labuhan Haji Kabupaten Labuhanbatu Utara.

Kualitas kerja pegawai PT. Perkebunan Nusantara III Labuhan Haji dapat dilihat dari penilaian karyawan terhadap indikator kualitas kerja yang digunakan dalam penelitian ini. Para karyawan memberikan nilai baik pada indikator karyawan harus mempunyai ketrampilan, yang menunjukan bahwa karyawan harus mempunyai ketrampilan, harus mempunyai pengawasan ilmu yang luas yang dimiliki karyawan, selalu memberikan pengawasan teknis kepada karyawan, karyawan diberikan pengetahuan dan pemberian pelatihan tujuan agar para karyawan memiliki pengetahuan, kemampuan dan ketrampilan sesuai dengan tuntutan pekerjaan yang mereka lakukan.

Kualitas kehidupan kerja merupakan masalah utama yang patut mendapat perhatian 


\section{Jurnal Ecobisma Vol 5 No. 2 Juni 2018}

organisasi, hal ini merujuk pada pemikiran bahwa kualitas kehidupan kerja dipandang mampu untuk meningkatkan peran serta dan sumbangan para anggota atau karyawan terhadap organisasi. Penelitian terdahulu menunjukkan bahwa kualitas kehidupan kerja mempunyai pengaruh positif dan signifikan terhadap kinerja perusahaan. Demikian juga dengan promosi jabatan juga merupakan aspek paling penting dalam meningkatkan kepuasan kerja.

Adanya kualitas kehidupan kerja juga menumbuhkan keinginan para karyawan untuk tetap tinggal dalam organisasi. Penelitian juga menunjukkan adanya hubungan positif antara praktek kualitas kehidupan kerja dengan kinerja karyawan. Mampu berorientasi dan berinteligensi daya fikir diperusahaan kemampuan berfikir dan bertindak cepat terhadap suatu keadaan maupun permasalahan dengan hasil solusi yang dianggap terbaik dan efektif merupakan tujuan dari promosi jabatan dan kompensasi bagi karyawan.

Kepuasan kerja pegawai tidak lain menyangkut "berbuat yang terbaik" sesuai dengan persepsi pegawai, sehingga untuk dapat mengukur tingkat kepuasan pegawai dengan benar harus memakai dasar yang tepat dalam melakukan penelitian, yaitu mengetahui dengan tepat apa kebutuhan yang paling dianggap penting bagi mereka. Salah satu yang dapat mempengaruhi kepuasan kerja pegawai seperti adanya promosi pegawai perlu dilakukan oleh pimpinan, karena dengan promosi pegawai, tujuan organisasi dapat disampaikan dengan baik kepada seluruh karyawan

\section{2).Secara Serempak Promosi Jabatan dan Kompensasi Berpengaruh Pada Kepuasan kerja karyawan PT. Perkebunan Nusantara III Labuhan Haji Kabupaten Labuhanbatu Utara.}

Sesuai dengan hasil analisis yang telah diuraikan pada bagian sebelumnya, mengemukakan bahwa secara parsial variabel promosi jabatan dan kompensasi secara simultan atau bersama-sama mempunyai pengaruh yang signifikan terhadap kinerja karyawan PT. Perkebunan Nusantara III Labuhan Haji Kabupaten Labuhanbatu Utara.

Nilai R Square pada kolom ketiga (angka korelasi atau $\mathrm{r}$ yang dikuadratkan) sebesar 0,681. Nilai tersebut berarti bahwa sebesar 68,1\% kepuasan kerja karyawan PT. Perkebunan Nusantara III Labuhan Haji Kabupaten Labuhanbatu yang terjadi dapat dijelaskan dengan menggunakan variabel promosi jabatan dan kompensasi. Sisanya yaitu 31,9\% dapat dijelaskan variabel lain yang tidak termasuk dalam model penelitian ini.

Pada dasarnya kepuasan kerja karyawan merupakan hasil proses yang kompleks, baik 
berasal dari diri pribadi karyawan ( internal factor ) maupun upaya strategis dari perusahaan. Faktor-faktor internal misalnya motivasi, tujuan, harapan dan lain-lain, sementara contoh faktor eksternal adalah lingkungan fisik dan non fisik perusahaan. Kinerja yang baik tentu saja merupakan harapan bagi semua perusahaan dan institusi yang mempekerjakan karyawan, sebab kinerja karyawan ini pada akhirnya diharapkan dapat meningkatkan kinerja perusahaan secara keseluruhan.

Hasil penelitian ini sejalan degan teori mengatakan bahwa jika karyawan dipromosikan berdasarkan asas keadilan dan objektivitas, karyawan akan memperoleh kompensasi yang lebih tinggi dan terdorong bekerja giat untuk dapat meningkatkan kinerja, sehingga sasaran perusahaan dapat dicapai (Kadarisman, 2012). Hal ini berarti kinerja karyawan akan terpacu bila kompensasi yang diberikan perusahaan sebagai ganti atas jerih payah yang diberikan oleh karyawan sesuai, karena mereka cenderung merasa pekerjaan mereka lebih berarti dan sesuai dengan pengorbanan mereka kepada perusahaan dan tentu akan mempertahankan kinerja baik mereka atau bahkan meningkatkan kinerja mereka.

\section{KESIMPULAN}

1. Secara parsial variabel promosi jabatan berpengaruh positif dan signifikan terhadap kepuasan kerja karyawan sebesar 0,764 artinya bahwa setiap terjadi penambahan promosi sebesar 0,764 maka kepuasan kerja karyawan PT. Perkebunan Nusantara III Labuhan Haji Kabupaten Labuhanbatu Utara bertambah sebesar 1 kali.

2. Secara parsial variabel kompensasi berpengaruh positif dan signifikan terhadap kepuasan kerja karyawan PT. Perkebunan Nusantara III Labuhan Haji Kabupaten Labuhanbatu Utara sebesar 0,112 artinya bahwa setiap terjadi penambahan kompensasi sebesar 0,112 maka kepuasan kerja karyawan PT. Perkebunan Nusantara III Labuhan Haji Kabupaten Labuhanbatu Utara bertambah sebesar 1 kali.

3. Promosi jabatan dan kompensasi secara bersama - sama berpengaruh positif dan signifikan terhadap kepuasan kerja karyawan PT. Perkebunan Nusantara III Labuhan Haji, hal ini terlihat dari uji parallel nilai R Square pada kolom ketiga (angka korelasi atau r yang dikuadratkan) sebesar 0,681 atau sebesar $68,1 \%$, sisanya yaitu $31,9 \%$ dapat dijelaskan variabel lain yang tidak termasuk dalam model penelitian ini. 


\section{Jurnal Ecobisma Vol 5 No. 2 Juni 2018}

SARAN

Berdasarkan kesimpulan, maka diajukan beberapa saran sebagai berikut :

1. Untuk memberikan promosi jabatan kepada karyawan sebaiknya ditingkatkan oleh pihak manajemen dengan cara memberikan kesempatan untuk mengisi jabatan yang sesuai dengan keahlian yang dimiliki karyawan dan memberikan penghargaan kepada karyawan yang mempunyai prestasi kerja.

2. Selain hal tersebut disarankan juga agar promosi jabatan, kompensasi perlu diberikan sesuai dengan UMK, agar dapat meningkatkan kinerja dan kepuasan kerja karyawan, oleh karena itu, promosi jabatan dan kompensasi yang tinggi maka akan mempengaruhi kinerja karyawan dalam mencapai target yang telah ditetapkan oleh perusahaan.

3.Untuk meningkatkan pengaruh dari kompensasi perlu dilakukan pembaharuan,seperti cara pemberian kompensasi dan keterbukaan dalam pembagian kompensasi sesuai peraturan yang telah ditetapkan agar ini akan menjadikan kompensasi berpengaruh tinggi terhadap Kepuasan karyawan.

\section{DAFTAR PUSTAKA}


Arikunto, 2010 . Prosedur Penelitian Suatu Pendekatan Praktik, (Edisi Revisi), Jakarta :

Penerbit Rineka Cipta

Hasibuan, Malayu S.P. 2012. Manajemen Sumber Daya Manusia, Edisi Revisi. Jakarta: Bumi Aksara

Handoko, T. Hani. 2012. Manajemen Personalia dan Sumber daya Manusia , Penerbit Yogyakarta BPFE

Kadarisme. M. 2012. Manajemen Pengembangan sumber daya manusia, Edisi Pertama, Penerbit Rajawali Press, Jakarta.

Siagian, Sondang, P., 2013, Manajemen Sumber Daya Manusia, edisi pertama, cetakan kedua, Penerbit : Bumi Aksara, Jakarta

Sugiyono, 2014, Metode Penelitian Bisnis, cetakan ketujuh, Penerbit : Alfabeta, Bandung.

Rivai, Veithzal, 2005. Manajemen Sumber Daya Manusia, Penerbit : Jakarta, Raja Grafindo Persada 